\title{
<特別講演 $>$
}

\section{新しいセラミックスについて}

\author{
東北大学名誉教授
}

梅屋薰

\section{I. プロローク}

セラミックスが次世代の工業技術を背負うチャンピオ ンとして華々しく登場して来たのは，今から数えて僅か 10 年程前のことでしかない. 米国では 20 年位前から Ceramic Age とい5言葉がもてはやされていたので, それからみれば 10 年遅れでわが国の Ceramic Age が 開花したことになる．しかし花が咲き始めてからの進展 には誠に目覚しいものがあって，またたく間に欧米の水 準に追いつき，今では追い越している部分さえかなり出 ているといらのが現状である.

他の近代工業技術が産業革命以来の僅加数百年の歴史 しか持っていないのに対して, Ceramics 技術は 80 世紀 すなわち 8,000 年以来の歷史に裹づけられているもので ある. それが何故にここ 10 年以来急速に異常ともいえ るような脚光の浴び方をしているのか？については， それ自身きわめて興味ある課題なのである。ここではそ の中からモーダンセラミックスについての現状の紹介を 行いたい.

\section{II. セラミックスの 4 つのジャンル}

昔は岩石を彫刻して，例えば皿なら血の形状にし用途 に供したいわゆる石器である.しかしこれでは多量生産 に向かないので，岩石をいったん粉にし，これを水で固 めて練土（粘土）とし，この練土を造形することにより 器物の形状を造形し，造形後は造形のためのみに必要と された練土中の水分を除外（乾然）することによって取 り出し，後これを焼き固め（焼結）して，もとの岩石質 に還元し，用途に供するようになった。これが炻器（後 出)である.

この焼き固めの際, 焼結温度が低いときには, 粉体間 隙に存在する空気相の構造体（空気の紐）は連続構造を 維持しているので, 器物の内部と外部とでは, この空気
の立体網によって繁がっている．これが土器 (Earthenware）である. 焼結温度が上昇するとこの空気 の紐の 立体網はその断面の細い所で括られて気泡化を果たすよ うになる. 斯くしてすべての気孔の立体網が気泡化を終 了し, 気相部分が不連続化してしまうと, 始めて炻器 (Stone ware) となるのである.

すなわち炻器化した時点では未だ気泡状態で空気相を 含有している．これをその焼結温度で保持するか，ある いはさらに温度を上げると, 気泡中の空気成分は熱拡散 して, 系外に除去されて行き, 終わりには気相分雲とな って Ceramic 相のみの器物となってしまう。これを完 全炻器と呼んでいる.

土器に釉 (Glaze) を掛けたものが陶器 (Pottery ware) で, 炻器に釉を掛けると磁器 (Porcelain ware) である.

したがって Ceramicsには土器・罂器・炻器ならび に磁器の 4 つのジャンルが成立し, その各々において独 得の Engineering Ceramics が成立する.

\section{III. 第 1 ジャンル（土器）における エンジニアリングセラミックス}

土器の Engineering Ceramics は, 煉瓦工業において 開花した。特に製鉄 (Eiron making)・製鋼 (Steel making）工業における耐火物素材として展開を果した。

土器は前記したようにボディ（器体）中に空気の立体 網が四通入達した構造体となっているが，その空気の紐 の均質性（どの紐をとり出して見ても構造・形状が均 質）ならびにその分布の均質性（どこの部分を採出して みても紐部分としての気相含有量が均質)であるという 2 種類の均質性を高度に要求される.

わが国では古来縄文土器という優れた土器の製造技術 を有していた。そのため土器質 Engineering Ceramics の製造技術には，きわめて高度な内容に裏つけられてい た，わが国の製鉄・製鋼技術は世界に冠たるものである ことは衆知の所であろうが，それを支えていた高度の耐 
火物技術のあったことを改めて指摘しておきたい.

\section{IV. 第 2 ジャンル (陶器) のエンジニア リングセラミックス（I）}

土器はそのままでは使用中に污れやすい、これを防ぐ ために釉（うわぐすり，グレーズ，Glaze）をかけるこ とが行われた。

土器の長所の多くは四通入達した空気紐の存在に起因 するのであるが，しかしこれに釉を掛けるとせっかくの 空気の紐による連続性が遮断されるので，それを防止す る意味で釉に貫入という微細なひび割れ部を作り，これ によって気孔との連続性を継続さすことが行われてい る. 釉で表面を化粧しながら土器質の長所を失わないで 済むように計うのである。

施釉屋根瓦は斯くして工業製品化された。施釉してあ ると污損保護のみでなく表面滑り性も良くなるので, 降 雨・積雪時に対して長所を発揮出来る.

外部施釉の Engineering Ceramics としてのもう1つ の顕著な実施例は，スペースシャトルのオービター船に 装着されたセラミックタイルであろう。これはオービタ 一船が大気圈再突入時に空気摩擦により発熱するが，そ れを防御するために装着する断熱 Ceramic 体である が，特別に含有空気量を多くした土器質とするためガラ 又繊維 (Ceramic fiber) を接点間焼結体とし，それに外 部施釉を施すことにより完成された。在来の陶器質に較 べ数倍もの空気含有量とすることが可能となる結果その 熱遮断性はきわめて良好となるのである.

\section{V. 第 2 ジャンル (陶器) のエンジニア リングセラミックス（II）}

上記した瓦の例は釉を器物表面に施釉した例である が，施釉にはこの表面施釉の外に内部施釉という別の方 法がある，それは器物表面にではなく，気孔紐の気孔表 面（内部表面）に施釉する方法である.

わが国特有の屋根瓦技術に雷瓦の技術といらのがあ る. 主として社寺建築用に用いられる瓦であるが，これ は土器質に焼成した瓦素地を温度を，その高温に保った まま，往時は松のまきのような長焰性燃料を使用するこ とにより，現時では別の方法も開発されているが，油煙 化して，その時発生する炭素の微粒子を蒸着して行くの である。

発生期の炭素は超微粒子である一方，その形状は板状
（フレーク状）(直径 $\mu \mathrm{m}$ 台, 厚さサブ $\mu \mathrm{m}$ 台, 六角板状) であるので，これが気孔内表面積部にカード・パック状 態となって沈着 (吸着)することにより気孔内表面が施 釉される.

瓦をこのように内部施釉すると（煓瓦とすると），降 雨時には雨水の大部分は瓦表面を流れ落ちるが，その一 部分は瓦の素地（ボディ）中に吸蔵されるので，睛天時 にその吸藏水分を建築の内外に排出することになり，水 分の吸脱着による呼吸機能を発揮出来るのである．斯く してわが国の木造建築の長寿命化に貢献できるのであ る．燯瓦とは年間降雨量のきわめて多量である．わが国 に産れるべくして産れた画期的な陶器技術なのである.

この燯瓦の技術を Engineering Ceramics として採り 入れた最初のものは，カーボン・セラミックス系耐火材 料である. Ceramics としてはマグネシア $(\mathrm{MgO})$ 采, ドロマイト采 $(\mathrm{CaO} \cdot \mathrm{MgO})$ 系などが使用されるが，い ずれの場合も土器質に焼成後, 気孔内部表面を内部施釉 したものである．転炉製鋼用・電気炉製鋼用耐火物とし て，わが国の製鉄・製鋼技術に多大の貢献を果して来た ことは誇示して良い内容といわねばならない。

脱硝用触媒として，この技術を用いたものの 1 つにチ タン白土器質八ネカム体の例があげられる.工業用炬か ら排出する NOx 成分すなわち硝酸塩成分のため, 大気 污染が問題視されたのは今から数えると 20 位前のこと であるが，これに対し NOx 分解触媒の研究開発はたち どころに着手された. 上記したチタン白ベースの土器に, NOx 分解触媒活性物を内部施釉したハネカム体はその 成功例の 1 つなのである. 今ではこれを煙道部に装備す ることにより NOx 成分の無害化排出を可能としてい る.

自動車の排気についても空気污染の問題が同上うに発 生している．これに対しても例えば自動車エンジンのマ フラー中に, 毒性ガス分解用触媒を拽入することにより 解決に当たっている. その一例はコージライト系土器質 体に分解触媒活性体を内部施釉することにより果されて いる. 現在 $2,000 \mathrm{cc}$ 以上の排気量を持つエンジンに対 し実装備され無害化排気を果している.

\section{VI. 第 3 ジャンル (炻器) のエンジニア リンクセラミックス（I）}

炻器のエンジニアリングセラミックス化において最初 に注目されたのは，脆性の改善といらテーマであった.

脆性はセラミックスを特徽づける特質の 1 つである. 
脆性改善に成功して脆性が全くなくなってしまったとし たら，もらその時はセラミックスではないとまでいわれ たものであるが,しかしそうはいっても，セラミック材料 を工業材料として使用する時には，脆いといら性質すな わち強度の下限值の所でばらつきが顕著であることは, 材料としての信賴性に欠けることになる.したがって, 脆性の改革の方向に研究開発が集中することになった訳 である. その結果, 出発物質の粉体を微粒化すること, また等径粒化することによって，かなりの程度まで脆性 改善に資することが出来るようになった。

従来の Ceramics においては, 出発物質である粉体は 粒度分布を持っていて，面もその形状は球形以外の形状 を持ったものであった，それが原因となって炻器化した 場合, ボディ中に大きさならびに形状の不揃の気泡群を 含有することになっていた．したがってこれを応力の場 に唒らす場合, 大きな気孔の小さな $\mathrm{r}$ 部分に集中応力の 発生を避けることが出来ないようになり，全体としては 未だ十分応力に耐え得る筈なのに，低い応力值の元で破 壊してしまう，つまり脆い性質を暴露することを余儀な くされていた.

これを球形に近い，また等径に近い超微粒子（ $\mu$ 以下 あるいはサブミクロン以下）に出発物質を揃えたため, 応力場の分散が可能となり，応力集中による低応力下の 破壊を防止出来るよ5になって来たのである.斯くして 最近のエンジニアリングセラミックスにおいては脆さか ら解放されるようになって来ている.

も5 1 つの脆性改革の道は, 半安定化ジルコニアセラ ミックスで到達された結果が示しているように, ボディ 中に 2 種類の結晶組織を持つ構造体化し, 态力が引加さ れた場合, その二種類の結晶間に部分転位を発生させる ことにより，応力吸収が行われるよう材料設計されるも のである.

このようなことが効を奏した結果, 最近のセラミック スでは, 強度值も高くまた脆くもないものとなり, 実用 面の拡大を達成しているのである.

自動車用エンジン部品・タービン用部品・各種機械用 部品等に用いられるまでに信頼性を高め得るに到ってい る.

\footnotetext{
VII. 第 3 ジャンル (炻器) のエンジニア リンクセラミックス（II） ーマーシーナフルセラミックスについて一
}

下限值を上げることにより脆性の改革を行い信頼性の
向上を計かる一方において，いわゆるマーシーナブルセ ラミックスといわれる焒器質エンジニアリングセラミッ クスも登場するに到っている. マーシーナブルセラミッ クスというのは丁度木材を飽で削るよ5にして，切屑を 出しながらセラミック材を切削して行くのである.

最初コーニング社 (米)により導入されたアルミノシ リケート質炻器 (商品名マッコール) で実施されたが, その後 3 品種の切削可能なセラミックスが追加提供され るに到っている.

これを用いれば，㯀盤で鉄材をひき出す時のように， セラミック材を直接金属バイトあるいはセラミックバイ 卜を用いて，切削による造形加工を行らことが出来る.

このようにして元来後加工の不可能であったセラミッ クスに後加工性を附与出来るようになったので, セラミ ックスを新たに素材として提供する道が拓かれたことに なり，新たな販路の抎張を可能とすることになった.

セラミックスをマーシーナブル化するには例えば， 、 ッコールにおいて行われているように, ヘッカイ性の素 材の微粒子充填体を焒器化することにより，材料のへッ カイ面を貫通して，次々に剝離を起こして行き，これに より切削加工の途を拓くようにしたものである.

\section{VIII. 第 4 ジャンル (磁器) のエンジニア リングセラミックス}

磁器は(2)節の説明からもわかるように, 炻器が釉を冠 ったものである(外部施釉). 炻器は空気孔網が連続し ておらず気泡として閉じ込められているので, 表面に施 釉する釉に貫入（前節）を入れなくても空気の流路のさ またげとはならない。したがって本来は無貫入が建前と なっている.

磁器のエンジニアリングセラミックスにおいては, 磁 器碍子を筆頭にあげて説明しなくてはならない，高圧送 電線の送電圧を絶縁する碍子の一種に䝮垂碍子，あるい は長幹碍子と呼ばれているものがある。これらは特に高 圧電源に対する絶縁が要求される，また，落雷時や短絡

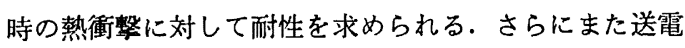
線システムとしての機械的強度も要求される. 特にわが 国のよ5に台風圏にある所での使用に対しては，この面 での要求特性もきわめて撖格である.

このよ5に電気的にも熱的にもはたまた機械的にも高 度特性が要求されるので, 炻器素地のみでその全部を力 バーすることは出来ない，しかしこれに強化焼ばめ釉の 特性を適用することにより，機械特性の中 $2 \sim 3$ 割を授 
けることが出来る，すなわち補強出来るようになるので 機械特性としての余力に恵まれることになり，それだけ 熱ならびに電気特性の方に組成設計をシフトさせる余裕 が出来, その結果現在の最高級送電用磁器碍子が得られ ている訳である.

自動車あるいは航空機用の点火栓碍子もこれに劣らぬ エンジニアリング磁器セラミックスの代表例である. 特 に碍子を起点としていわゆるアルミナ質炻器ならびに磁 器としての技術展開が開花したので歴史的にも注目され ている所である.

以上第 1 より第 4 ジャンルのセラミックスすなわち土 器・陶器・炻器ならびに磁器について, それぞれの分野 におけるェンジニアリングセラミックスについての紹介 を終った訳である.いずれもこの 10 年間の目覚しい展 開に成功し，今日の Ceramic Age を支えるに相応しい ものとなっている.

最後に筆者がごく最近行ったエンジニアリングセラミ ックスについて紹介し，絞姡りとしたい。

\section{IX. 合成珊瑚の開発}

ルビー, サファイヤ，キャッッアイ，ダイヤモンド等 多くの宝石が合成されている，また琥珀や翡翠に到るま で合成品が完成し，天然品と優劣を争うまでになってい る.

しかし栅瑚と真珠のみは，いまだ天然品に追従できる 合成品は完成されていない. 筆者たちの研究室では, これ に挑戦してみた結果,かきの殼を原料にして,これに他の 助剂を調合することにより天然珊瑚と同質の Ceramics 素地の合成を可能とした。

天然珊瑚には多くて七色しか変化が存在していない。 しかし合成珊瑚にするときはさらに多色について合成で きるので，天然に全くない色彩・色調を持った珊瑚素地 の提供を可能とするようになった，また，天然珊瑚は地 脈 (脈理) 模様が全くのあてがいぶちであるのに対し， 合成珊瑚においては脈理の設計を可能とする.したがっ て天然にない脈理模様を新設計した新種の哺瑚の提供を も可能とする訳である.

天然の真珠は，真珠只すなわちあこや貝に「核石」を 抱かせて, 貝にその石を核に真珠層を被覆させて作り上 げる訳である。この核になる石は，現在アメリカからの 輸入品で, しかも年々良品質のものが枯渴して行き輸入 単価が高騰している. 上記の合成珊瑚材質が天然珊瑚と 寸分違わないということで，あるいはあこや貝が騙され
て抱き込んでくれるかもしれない。もしそうであれば輸 入品の国産化が出来る.また核の大粒化も望めるかもし れない，そらすれば大粒真珠を短期間の中に作り出させ ることが可能である．このよらな夢は，上記の合成珊瑚 の成品化と同時に並行開発され，今日ではその 2 つの夢 は両方とも実現性を帯びて来ている.

この場合も核に着色玉を与えることにより，着色真珠 を養殖出来ることになる. 今までにも少数の着色真珠は 存在し得ていたが, 何れも限られた少数の色調の範囲内 のことであった。しかし合成珘瑚ではきわめて変化に富 んだ色彩籁囲を実現出来るので，これを真珠核として与 えることにより，真珠においても在来にない新しい色調 の真珠を天然真珠として採り出すことが出来るのであ る.

\section{X. 年輪をもった石材の開発}

わが国の彫刻は天平時代の仏像からもらかがえるよら に木材質を素材としたものである. この場合木質として の木目 (年輪模様) が, 装飾性の大きい部分を占めてい る.

ギリシャ彫刻は，これに反し，大理石が素材となって いる，勿論大理石にも脈理模様のあるものもあるが，郕 刻の素材となるものは無地のものが主となっている.

もし石材中に年輪模様を合成出来たとしたら，和洋の 素材の両長所を合体出来るので，新しい彫刻素材として 迎えら㣗得るであろら。

そうしたら，彫刻素材としてのみに止まっていないで あろら。より広く建築材料等として新展開も見込まれる であろう。

こんな展望から年輪模様を合成した Ceramics の合成 に挑戦してみた。土器質・炻器質・陶器質ならびに磁器 質すべてのジャンルにおいて年輪を内在させた新セラミ ック素地の開発を遂行中である.

新しい合成木材質 Ceramics としての展開を夢見なが らの開発となっている。

\section{XI. エピローグ}

以上でェンジニアリングセラミックスの現状について の紹介を終りたい。

Ceramic Age と呼ばれるに相応しい展開が眼覚しく 行われていることに皆様のご注意を換起して 終りとす る. 